
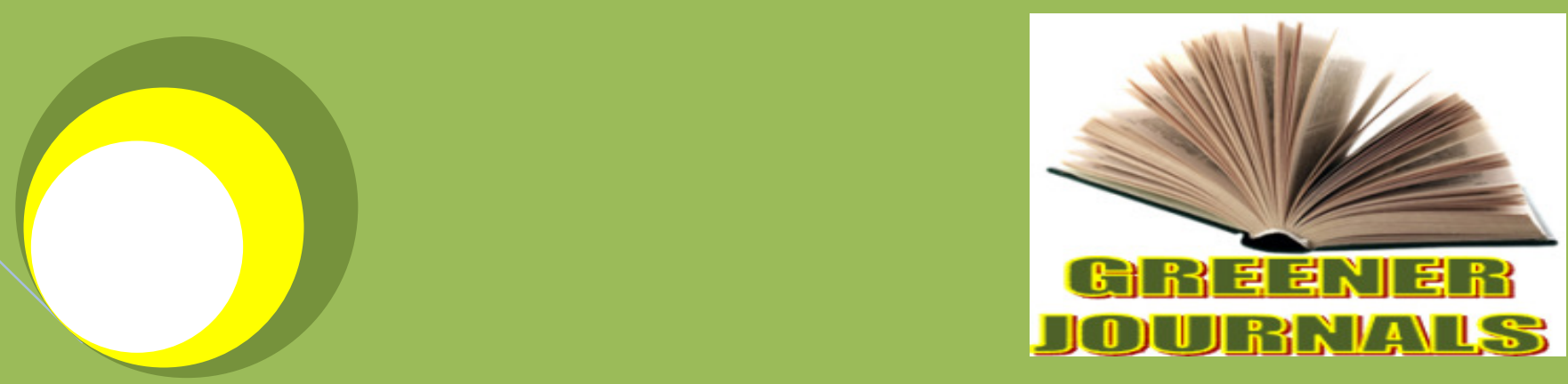

Greener lournal of fipidemiology and Publichtealith

Heavy Metal Residues in the Bottom-Ash of Incinerators Treating Health-Care Waste: A Case of the Two National Teaching and Referral Hospitals in Kenya By

Nkonge Njagi Ananias Ndwiga Taratisio Prof. Magambo K Japhet Prof. Oloo Mayabi Dr. Kithinji Jacob 


\title{
Heavy Metal Residues in the Bottom-Ash of Incinerators Treating Health-Care Waste: A Case of the Two National Teaching and Referral Hospitals in Kenya
}

\section{${ }^{* 1}$ Nkonge Njagi Ananias, ${ }^{2}$ Prof. Oloo Mayabi, ${ }^{3}$ Dr. Kithinji Jacob ${ }^{4}$ Prof. Magambo K. Japhet, and ${ }^{5}$ Ndwiga Taratisio}

\author{
${ }^{1,5}$ Department of Environmental Health, School of Public Health, Moi University P.O BOX 4606 code 030100 \\ Mobile: +254722609366 Eldoret Kenya. \\ 4 \& 2 Jomo-kenyatta University of Agriculture and Technology P.O BOX 62,000 - 00200 Mobile: \\ +254714116815 Nairobi Kenya. \\ ${ }^{3}$ Departments of Chemistry, University of Nairobi, and P.O. BOX 30197 Code - 00200 Nairobi.
}

${ }^{1 *}$ Corresponding Author’s Email: annkonge@gmail.com

\begin{abstract}
Incinerated medical waste residue has more heavy metals than municipal solid waste which if not well disposed of, could pollute the environment and pose a great danger to public health.

A study was done on incinerators at Kenyatta National Hospital - Nairobi and Moi Teaching and Referral Hospital - Eldoret to assess levels of total chromium, cadmium, mercury, lead and silver from the bottom ash. Atomic absorption spectrophotometer was used for analysis.

At KNH, incinerator bottom ash had mean concentrations of 5297, 140, 4299, 2092 and $57 \mathrm{mg} / \mathrm{kg}$ of total chromium, cadmium, lead, silver and mercury respectively. At MTRH, the concentrations in the ashes of 3870, 250, 4340, 1360 and $40 \mathrm{mg} / \mathrm{kg}$ of total chromium, cadmium, lead, silver and mercury were found. These exceeded the maximum limits specified by the Kenyan National Environmental Management Agency and European Union Standards for ordinary disposal. Regular quality monitoring of heavy metals in bottom ash of the two institutions' incinerators to guide safe disposal of the residues was not practiced.
\end{abstract}

Keywords: Heavy metals; concentrations; quality monitoring; standards.

\section{INTRODUCTION}

Medical waste forms $10 \%$ to $25 \%$ of the health-care waste which is considered as hazardous and may be toxic or radioactive (WHO, 1994). Its management calls for a heavy responsibility, as it is dirty, foul, difficult, expensive and technically complicated task. If not done properly it can cause a significant inconvenience and become a public health risk (Naioova, 2000; Sheshinski, 2002; WHO, 2004). A poor management practice mail pose as a health risk which according to Ford et al. (2004) may likely pollute the environment through emitted smoke and improperly disposed of bottom ash of incinerators. Incineration of hazardous waste as a treatment option is viewed as dangerous (Ridlington and Heavner, 2004). The practice is worsened by operation of incinerators by untrained or improperly trained operators. (Batterman, 2004).

While incinerating medical waste, waste that may contain heavy metals should be segregated and excluded for alternative treatment that ensures that the environment is not polluted by their emissions and heavy metal residues in the bottom ash. Healthcare waste containing for example mercury, incinerated without due care would release mercury vapour in the environment which if inhaled by humans may be toxic, fatal or lead to life threatening injuries to lungs and neurological systems (Howard, 2002; UNEP, 2009). Health-care waste has more heavy metals than municipal solid waste (Takeuchi et al., 2005; Sabiha-Javied and Tufai, 2008; Zhaho et al., 2010). Waste from dental clinics, broken thermometers mistaken as sharps contain mercury (US, EPA, 2011; Vieira et al.,2009; Mazrui, 2010; Calhoum, 2003) which if incinerated leave mercury residue in the bottom ash while the rest is released as gaseous emission in the environment posing a great risk to public health. Cadmium, a heavy metal also common in 
red bags used to store infectious waste ( Hill, 1997; Lee and Huffman, 2002) if incinerated and taken by humans, bioaccumulates in kidneys with the content increasing with age. It causes human kidney damage and emphysema.

Chromium vi, also a product of incinerated plastics leather treated products in industry, if incinerated and gaseous emissions inhaled or consumed orally (chromium vi) can cause cancer (WHO, 1996; Howard, 2002).

Lead commonly found in paints and plastic liners of health-care waste bins if released in the environment acts as a cumulative poison, and has adverse effect on nervous system of developing fetuses, and could cause convulsion, comma, renal failure and death (Hill, 1997; Howard, 2002).

Silver, a metal associated with photographic materials used in X-Ray films and also present in dental amalgam if released during incineration and excessively ingested, could cause skin, eyes and mucous membrane discoloration (Hill, 1997). In its ionic form, it is more toxic to aquatic organisms than any other metal except mercury.

\section{METHODOLOGY}

Daily single batches with samples taken in triplicates from bottom ashes of selected incinerators, one each, at $\mathrm{KNH}$ and MTRH were weighed in equal quantities for thirty consecutive days in October and November, 2008.

The samples were later sieved and weighed in $1 \mathrm{gm}$ quantities. Digested and the extract analysed for heavy metals applying a standard method (Endham et al., 2000) and use of Atomic Absorption Spectrophotometer (AAS).

\section{RESULTS AND DISCUSSION}

\section{Bottom Ash Analysis}

The following were the mean daily concentrations of the heavy metals under study as isolated from the incinerators bottom ash:

- $\quad$ NEMA- National Environmental Management Authority.

- $\quad$ WSRP- Water Services Regulatory Board.

- US, EPA- Environmental Protection Authority of United States.

Table 1.0: Heavy Metals in Bottom Ash of Hospital Incinerator (KNH)

\begin{tabular}{|l|l|l|l|l|l|}
\hline $\begin{array}{l}\text { Item } \\
\text { (day) }\end{array}$ & $\begin{array}{l}\text { Chromium } \\
\mathrm{mg} / \mathrm{L} \\
\text { (daily mean } \\
\text { conc.) }\end{array}$ & $\begin{array}{l}\text { Cadmium } \\
\mathrm{mg} / \mathrm{L} \\
\text { (daily mean } \\
\text { conc.) }\end{array}$ & $\begin{array}{l}\text { Lead } \\
\mathrm{mg} / \mathrm{L} \\
\text { (daily } \\
\text { mean } \\
\text { conc.) }\end{array}$ & $\begin{array}{l}\text { Silver } \\
\mathrm{mg} / \mathrm{L} \\
\text { (daily mean } \\
\text { conc.) }\end{array}$ & $\begin{array}{l}\text { Mercury } \\
\text { mg/L } \\
\text { (daily mean } \\
\text { conc.) }\end{array}$ \\
\hline Mean & 5.297 & .140 & 4.299 & 2.09193 & 0.057 \\
\hline SD & 2.486759 & .054081 & 1.881 & 0.74403 & 0.018 \\
\hline Variance & 6.18 & 0.00 & 3.53 & 0.55 & 0.000 \\
\hline $\begin{array}{l}\text { Mean } \\
\text { mg/kg of } \\
\text { ashes }\end{array}$ & 5297 & 140 & 4299 & 2092 & 57 \\
\hline
\end{tabular}

Table 2.0: Maximum Permissible Levels (Standards)

\begin{tabular}{|l|l|l|l|}
\hline & Enforcing Body & Heavy Metal & Max. Conc. mg/L \\
\hline 1 & NEMA/WSRB & Lead & 0.01 \\
\hline 2 & - do - & Lead and it compounds & 0.1 \\
\hline 3 & - do - & Chromium (vi) & 0.05 \\
\hline 4 & - do - & Chromium (total) & 2.0 \\
\hline 5 & - do - & Cadmium & 0.01 \\
\hline 6 & - do - & Cadmium and its compounds & 0.1 \\
\hline 7 & & Total mercury & 0.005 \\
\hline 8 & EPA (US) & Silver & 0.14 \\
& & & \\
\hline
\end{tabular}


The mean operating temperatures for the incinerator at $\mathrm{KNH}$ were $188^{\circ} \mathrm{C}$ minimum and $902^{\circ} \mathrm{C}$ maximum.

The metals, chromium (total), cadmium and lead and mercury fall above the maximum levels permitted by the standards (National Environmental Management Agency/Water Services Regulatory Board Guidelines, 2006) levels as in Table 2.0 and are significantly higher than the standard, $p=0.000(\mathrm{df}=29)$. Similarly, silver is also significantly higher than the standard (United States Environmental Protection Agency) with a concentration of $0.14 \mathrm{mg} / \mathrm{l} ; \mathrm{p}=$ $0.000(\mathrm{df}=29)$.

The bottom ash had therefore a mean concentration of heavy metals of total chromium, cadmium, lead, silver and mercury of 5297, 140, 4299, 2092 and $57 \mathrm{mg} / \mathrm{kg}$ respectively. Zhao et al. (2008) demonstrated that bottom ashes from medical incinerators with heavy metal residues if not properly disposed of could leach from the ashes and pollute the environment.

Table 3.0: Heavy Metals in Bottom Ash of Hospital Incinerator (MTRH)

\begin{tabular}{|l|l|l|l|l|l|}
\hline $\begin{array}{l}\text { Item } \\
\text { (day) }\end{array}$ & $\begin{array}{l}\text { Chromium } \\
\mathrm{mg} / \mathrm{L} \\
\text { (daily mean } \\
\text { conc.) }\end{array}$ & $\begin{array}{l}\text { Cadmium } \\
\mathrm{mg} / \mathrm{L} \text { (daily } \\
\text { mean conc.) }\end{array}$ & $\begin{array}{l}\text { Lead } \\
\mathrm{mg} / \mathrm{L} \\
\text { (daily } \\
\text { mean } \\
\text { conc.) }\end{array}$ & $\begin{array}{l}\text { Silver } \\
\mathrm{mg} / \mathrm{L} \\
\text { (daily } \\
\text { mean } \\
\text { conc.) }\end{array}$ & $\begin{array}{l}\text { Mercury mg/L } \\
\text { (daily mean } \\
\text { conc.) }\end{array}$ \\
\hline Mean & 3.87 & 0.25 & 4.34 & 1.36 & 0.04 \\
\hline SD & 2.20 & 0.18 & 2.70 & 0.60 & 0.05 \\
\hline VARIANCE & 4.83 & 0.031 & 7.29 & 0.35 & 0.002 \\
\hline $\begin{array}{l}\text { Mean mg/kg } \\
\text { of ashes }\end{array}$ & 3870 & 250 & 4340 & 1360 & 40 \\
\hline
\end{tabular}

The mean operating temperatures for the incinerator at MTRH were $186^{\circ} \mathrm{C}$ minimum and $938^{\circ} \mathrm{C}$ maximum.

From the analysis, the mean levels of the five different pollutants (heavy metals) recovered from the bottom ash at $\mathrm{MTRH}$ incinerator are significantly higher than the levels specified by National Environmental Management Agency/Water Services Regulatory Board, standards for disposal in the environment or receiving water bodies.

All the metals, chromium (total), cadmium, lead and mercury are of higher concentrations than those permitted for disposal by National Environmental Management Agency and Water Services Regulatory Board Guidelines and are significantly higher, $p=0.000(d f=29)$. Similarly, silver concentration is significantly higher than the level specified by (United States Environmental Protection Agency), $p=0.000$ ( $\mathrm{df}=29)$ (same table).

The bottom ash with mean concentrations of heavy metals, total chromium, cadmium, lead, silver and mercury of $3870,250,4340,1360$ and $40 \mathrm{mg} / \mathrm{kg}$, respectively, which if not properly disposed of is likely to leach from the ashes and pollute the environment as indicated in the case of $\mathrm{KNH}$ above.

Incinerating healthcare waste bearing mercury risks public health as it readily sublimes, appearing as vapour in the environment and can be inhaled by humans. The positions of the two incinerators under study in the two institutions by virtue of their situation make render the heavy metals they discharge a public health risk. This is an obvious threat because when mercury in unacceptable concentration was traceable in bottom ash of incinerator, it implies that much of it had undergone sublimation and was discharged as mercury vapour in the environment in the two institutions. The healthcare waste likely to emit mercury during incineration, a heavy metal isolated from the bottom ash, includes dental amalgam from dental clinics which has 50\% mercury, (Calhoum,2003) thermometers, blood pressure cuffs, laboratory chemicals, certain electrical switches, paints, fluorescent lumps and bulbs (GAIA, 2009). Cadmium bearing waste that if incinerated could contribute to this heavy metal traced in the bottom ash would be red liner plastic bags used for refuse bins (Hill, 1997). Lead, which was also isolate in high quantities in the incinerators of the two institutions, would originate from incinerated red liner bags used for storage of infectious waste, paints and batteries (Hill, 1997; Howard, 2002). The origin for silver in the bottom ash of the incinerators must have been photographic material used for X-Ray films. The category was not among the four categories studied. 


\section{CONCLUSION}

Concentrations of heavy metals in the bottom ash of the incinerator under study at $\mathrm{KNH}$, total chromium, cadmium, lead, silver and mercury at 5297, 140, 4299, 2092 and $57 \mathrm{mg} / \mathrm{kg}$ respectively exceeded the maximum levels allowed for ordinary disposal in the environment by National Environmental Management Agency and the United States Environmental Protection Agency. At MTRH the concentrations of heavy metals in the bottom ashes, 3870, 250, 4340,1360 and $40 \mathrm{mg} / \mathrm{kg}$ respectively also exceed the maximum levels specified by the said standards.

There was no regular monitoring of heavy metal concentrations in the bottom ashes of the incinerators in the two institutions to quality to ensure for safe disposal of bottom ashes in the environment.

\section{ACKNOWLEDGEMENT}

The authors wish to thank the management of Moi University, Eldoret and Moi Teaching and Referral Hospital for financial support to complete this study. The approval of the study by National Science and Technology and Institutional Ethics Committees of $\mathrm{KNH}$ and $\mathrm{MTRH}$ is also appreciated.

Contribution by the research assistants at $\mathrm{KNH}$ and MTRH who utilized their familiarity and experience in the two institutions to collect the required data.

\section{REFERENCES}

Batterman S (2004). Findings on assessment of small-scale incinerators for healthcare waste, World Health Organization, Geneva, 2004: 1-65.

Availablefrom:<http://www.who.int/immunization_safety/publications/waste_management/en/Assessment_SSls-pdf>, Accessed on $18^{\text {th }}$. Aug. 2011.

Calhoun B (2003). Dental Amalgam and Mercury.

Available from: <http://www.stanford.edu/-bcalhoun/amalgam.htm.>, Accessed on 5th March 2011.

Endham J, Denney RC, Barnes JD and Thomas MJK (2000). Atomic Absorption spectroscopy. Textbook of Quantitative Chemical Analysis, 584-616. Addison Wesley, Longman. Singapore (PLC) Ltd.

Ford JN, Rennie MN, Falkoner K, Falconer L and Ray K (2004). Risk Management for Environmental Health. Handbook of Environmental Health. Edited by WH Basset. $19^{\text {th }}$ edn: 213-218, ISBN 0-415-31808-4.

Global Anti-Incinerator Alliance (G.A.I.A) (Feb. 2009). Mercury Rising. Reducing Global Emissions from Burning Mercury-added Products.

Hill MK (1997). Understanding Environmental pollution. Printed in USA: 224. ISBN 0521-36201-4.

Howard H (2002). Human Health and Heavy Metal Exposure. Available from: $<$ http://www.chge.med.havard.edu/programs/education/secondary/hhgec/documents/mccally,pdf.>, accessed on $5^{\text {th }}$ March 2011.

Lee CC and Huffman GL (2002). Metals Behaviour during Medical Waste Incineration. Environmental Protection Agency, U S.

Available from:http://www.anl.gov/pcs/Gcsfuel/preprintarchive/Files/36_4_New York_08-91-1735.pdf>, accessed on $8^{\text {th }}$ April 2011

Mazrui N (2010Ma). The Waste of Modernity. Medical Waste Management in Kenya: Opportunities for Improvement. Tropical Resources. The Bulletin of Yale Tropical Resources Institute. Volume: 29.

Available from:<http://www.environment.yale.edu/tri/uploads/Nashaat_mazrui.pdf.>, Accessed on13th June 2011.

Naioova M (2000). Solid Waste Characterization Study and Management Plan for the Republic of Kiribati AACP Country)

Available from: < http://www.sprep.org/att/publication/00035/Solid Waste

Characterization PNG.pdf.>, accessed on $15^{\text {th }}$ Dec 2010.

Ridlington E and Heavner B (2004). Medical Waste in Maryland. Alternatives to Incinerations, 4-23. Mary -PIRG Foundation, 3121 Saint Paul Street, Baltimore, MD 21218. Kathleen Krushas, Point Publications.

Sabiha-Javied M and Tofail SK (2008). Heavy Metal Pollution from Medical Waste Incineration at Islamabad and Rawalpindi, Pakistan. Microchemical Journal. 90 (1): 77-81.

Sheshinski RH (2002). Indirect data collection for waste statistics and waste indicators. Statistical Journal of the United Nations, ECE, 19: 53-63.

Takeuchi H, Kikuchi I, Kitade M, Kumakiri J, Kinoshita K, Yuka TRN and Eniko TRN (2005). Disposal Laparoscopic surgical instruments and the economic effects of repackaging.' Journal of Laparoendoscopic Surgical Techniques, 15, No.2, 2: 176-181. 
United Nations Environmental Programme (2009). Study on Health and Environmental Effects of the Movement of Products Containing Lead, Cadmium and Mercury in Africa. 18/08/2011.

Available from: < http://www.unep.org/gc/gcss-x/download.asp? ID=1068 >, accessed on $18^{\text {th }}$ Aug. 2011.

Vieira CD, de-Carvalho MAR, Cussiol, NA de M, Alvarez-Leite, ME, dos Santos SG, Gomes RM, da F, Silva MX and Farias de LM (2009). Composition Analysis of Dental solid Waste in Brazil. Journal of Waste

World Health Organisation (1994). Managing Medical Wastes in Developing Countries. Report of a Consultant on Medical Wastes Management in Developing Countries.

World Health Organisation (1996). Health criteria and other supporting information. Guidelines for Drinking Water Quality $2^{\text {nd }}$ edn, Vol. 2: 206-213; 254-256; 285-293. ISBN 924 154480-5 (v.5) (NLM Classification.WA675).

World Health Organisation (2004). Health-care Waste Management. Fact Sheet No. 281.Available from :<http:www.who.int/mediacentre/factsheets/fs281/en/index.htm.>, Accessed on $15^{\text {th }}$ Dec.2010.

Zhao L, Zhang FS, Wang K and Zhu J (2008). Chemical Properties of Heavy Metals in Typical Hospital Incinerator Ashes in China. Journal of Waste Management. 29 (3):1114-21.

Zhao L, Zhang FS, Chen M, Liu Z and Wu DJ (2010). Typical Pollutants in the Bottom Ashes from a Typical Medical Waste Incinerator. Journal of Hazardous Materials, 173: 181-185. Management, 29: 1388-1391. 